\title{
REVIEW: PRODUKSI, KARAKTERISASI DAN APLIKASI SELULOSA BAKTERI DI BIDANG FARMASI
}

\author{
Claudio Ananda Boby ${ }^{1}$, Asep Roni ${ }^{1}$, Soni Muhsinin ${ }^{1 *}$ \\ ${ }^{I}$ Fakultas Farmasi, Universitas Bhakti Kencana, Bandung, Indonesia \\ email: soni.muhsinin@bku.ac.id
}

\begin{abstract}
Bacterial cellulose is a polymer that has a wide range of applications and promising in a variety of medical fields. The purpose of this literature review research is to carry out literature searches to investigate whether the substrate and fermentation conditions influence the quality of the resulting cellulose and its use in the pharmaceutical sector. The data collection method used was to conduct a literature study using search keywords: production and application of bacterial cellulose. This article is reviewed in the last 10 years that discusses the production, characterization, and applications of bacterial cellulose in pharmaceutical application. The article is obtained from various studies that have been carried out through search engines such as Google Scholar, PubMed, and Science Direct. Various studies have shown that the substrate, starter concentration, temperature, $\mathrm{pH}$, fermentation time and the purification process greatly affect the quality of the resulting cellulose. Characterization studies carried out include SEM, TGA, moisture content and mechanical properties. In the pharmaceutical application, the bacterial cellulose can be used to make wound dressings, drug carriers, and face mask materials, as well as emulsion stabilisers and tissue engineering.
\end{abstract}

Keywords: Acetobacter xylinum,Bacterial cellulose, Fermentation, Scanning Electron Microscopy (SEM), Thermogravimetric Analysis (TGA)

\begin{abstract}
ABSTRAK
Selulosa bakteri merupakan polimer yang memiliki aplikasi yang luas dan menjanjikan dalam berbagai bidang medis. Tujuan dari penelitian tinjauan pustaka ini adalah untuk melakukan penelusuran pustaka untuk mengetahui apakah substrat dan kondisi fermentasi mempengaruhi kualitas selulosa yang dihasilkan dan penggunaannya di bidang farmasi. Metode pengumpulan data yang digunakan adalah dengan melakukan studi kepustakaan dengan menggunakan kata kunci pencarian: produksi dan aplikasi selulosa bakteri. Artikel ini diulas dalam 10 tahun terakhir yang membahas tentang produksi, karakterisasi, dan aplikasi selulosa bakteri dalam bidang farmasi. Artikel tersebut didapat dari berbagai penelitian yang telah dilakukan melalui mesin pencari seperti Google Scholar, PubMed, dan Science Direct. Berbagai penelitian menunjukkan bahwa substrat, konsentrasi starter, suhu, $\mathrm{pH}$, waktu fermentasi dan proses pemurnian sangat mempengaruhi kualitas selulosa yang dihasilkan. Studi karakterisasi yang dilakukan meliputi SEM, TGA, kadar air dan sifat mekanik. Dalam aplikasi farmasi, selulosa bakteri dapat digunakan untuk membuat pembalut luka, pembawa obat, dan bahan masker wajah, serta stabilisator emulsi dan rekayasa jaringan.
\end{abstract}

Kata kunci: Acetobacter xylinum, Fermentasi, Selulosa bakteri,Scanning Electron Microscopy(SEM), Thermogravimetric Analysis (TGA). 


\section{PENDAHULUAN}

Selulosa bakteri merupakan polisakarida ekstraseluler yang diproduksi oleh Acetobacter xylinum yang memiliki morfologi bentuk batang (basil) dan termasuk golongan gram negatif. Selulosa bakteri yang dihasilkan oleh bakteri ini memiliki struktur serat nano dengan bentuk permukaan yang lebih padat di satu sisi serta lapisan seperti gel di sisi lain (Jozala et al., 2015). Ukuran hasil sintesis selulosa bakteri tidak lebih dari $100 \mathrm{~nm}$ yang berbentuk pita (Wibowo \& Isroi, 2015).Selulosa bakteri diproduksi melalui proses fermentasi yaitu suatu proses metabolisme karbohidrat dengan mengubah gula menjadi asam organik, gas, dan alkohol (Mani, 2018).

Rumus kimia selulosa bakteri sama dengan selulosa tumbuhan tetapi secara sifat kimia, mekanik,dan fisik berbeda. Selulosa bakteri memiliki beberapa keunggulan dibandingkan dengan selulosa tumbuhan, diantaranya: struktur serat berukuran nano yang sangat tipis (Novikov et al., 2021), dengan kisaran tipisnya serat membran yang terbentuk 100 kali lebih tipis (Rohaeti et al, 2016). Tingkat kemurnian yang lebih tinggi karena tidak mengandung lignin, hemiselulosa, dan Pektin (Badshah et al., 2018). Selulosa bakteri juga memiliki keunggulan yakni memiliki biokompatibilitas yang baik (Novikov et al., 2021). Biokompatibilitas sendiri merupakan suatu kemampuan material saat dipergunakan pada tempat yang spesifik pada organ tubuh dapat berinteraksi pada jaringan hidup/sel-sel namun tidak memicu atau menimbulkan suatu respon imun dan toksisitas (Ma'ruf, 2018). Selain itu selulosa bakteri secara alami mampu terurai dengan sangat baik (Ye et al., 2019) serta memiliki daya serap air yang tinggi (Novikov et al., 2021).

Pemanfaatan selulosa bakteri dibidang kesehatan sudah cukup banyak penelitiannya, diantaranya: sebagai kulit buatan untuk luka bakar, pembuluh darah buatan, dan teknik penyembuhan luka (Potivara \&Phisalaphong, 2019). Selain itu terdapat beberapa hasil penelitian pemanfaatan selulosa bakteri di bidang farmasi, kususnya kosmetik, diantaranya: penggunaan selulosa bakteri sebagai masker matriks wajah (Muhsinin et al., 2017), penstabil emulsi (Jia et al., 2016) matriks pembawa obat (Potivara \&Phisalaphong, 2019), dan bahan alternatif dalam pembuatan cangkang kapsul (Ullah et al., 2017).

Berdasarkan penelitian selulosa bakteri dapat diproduksi dalam berbagai media asalkan media tersebut minimal harus memiliki sumber nitrogen, karbon, makro, dan mikronutrient yang diperlukan untuk pertumbuhan mikroorganisme seperti fosfor, belerang, kalium, dan magnesium (Das \&Dash, 2020). Selulosa bakteri yang dihasilkan dilakukan pengujian karakterisasi untuk mengetahui kualitasnya (Potivara \&Phisalaphong, 2019). Karakterisasi selulosa bakteri dapat meliputi 6 pengujian yakniX-Ray Difraction (XRD), thermogravimetricanalysis(TGA), FTIR Fourier Transform Infrared Spectroscopy (FTIR), Water Absorption, Mechanical Properties, Scanning Electron Microscopy (SEM) (Shimpi, 2018). Oleh karena itu dilakukan review untuk mengetahui pengaruh perbedaan substrat dan kondisi proses fermentasi terhadap kualitas selulosa bakteri, mengetahui hasil karakterisasi selulosa bakteri yang meliputi SEM, TGA, mechanical properties, kadar air, serta pemanfaatannya di bidang farmasi.

\section{METODE}

Pengumpulan data dalam penulisan review jurnal diperoleh dengan menggunakan metode kajian pustaka, yang diperoleh dari suatu instrumen mesin pencarian secara online meliputi: Google Scholar, Pubmed, Elsevier. Pencarian jurnal dilakukan dengan menggunakan kata kunci untuk pencarian jurnal Internasional: Production and Application Of Bacterial cellulose and Pharmaceuticals, Biocellulose and utilization, production and utilization of cellulose bacteria, bacteria and biomedical fields, bacterial and wound dressing and cosmetic material, bacterial cellulose and structural characteristic, sementara untuk jurnal Nasional: Produksi dan Aplikasi Bakteri Selulosa. Artikel yang termasuk kriteria inklusi adalah waktu publikasi berkala terlama 10tahun terakhir (2011-2021), jurnal berbahasa Indonesia dan berbahasa Inggris, original artikel atau jurnal riset penelitian, jurnal mengenai proses produksi fermentasi selulosa bakteri meliputi: 
suhu, lamanya fermentasi serta karakterisasi menggunakan bakteri Acetobacter xylinum serta pemanfaatannya pada bidang farmasi. Sementara artikel yang termasuk kriteria eksklusi adalah jurnal yang keterangannya tidak lengkap, review artikel. Sehingga diperoleh artikel sebanyak 44 untuk dilakukan pengkajian

\section{HASIL DAN PEMBAHASAN}

\section{A. Proses pembentukan membran selulosa bakteri}

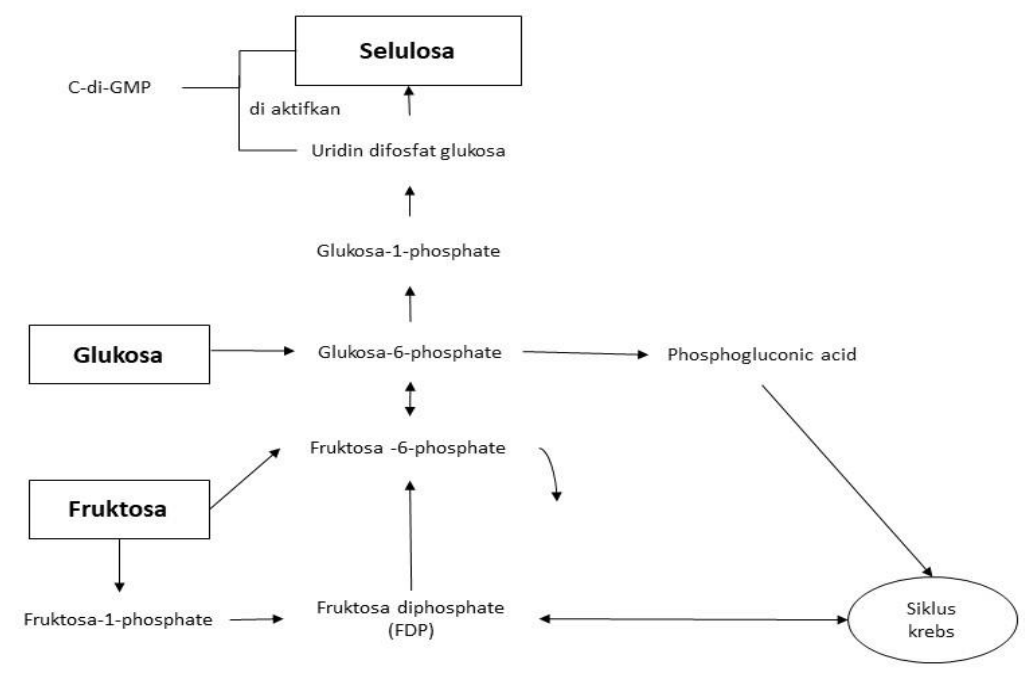

\section{Gambar 1. Proses pembentukan membran selulosa bakteri http://2017.igem.org/Team:TUST_China/Design}

Proses biosentesis pembentukan membran selulosa sangatlah bergantung pada sumber karbon dan nitrogen yang akan dipergunakan sebagai media fermentasi. Pembentukan membran selulosa bakteri dengan media limbah cair sagu dimulai dari lepasnya molekul precellulosicpolymermolecules pada permukaan sel bakteri yang kemudian terbentuklah suatu lapisan polisakarida di sekeliling dinding sel bakteri tersebut. Bakteri mengeluarkan benang protofibril yang kemudian akan saling berikatan membentuk untaian serat-serat halus membentuk membran selulosa (Yanti et al., 2021). Sementara sintesis selulosa bakteri yang menggunakan media limbah kulit pisang dapat terjadi karena kulit pisang mengandung sukrosa. Acetobacter xylinum mengeluarkan enzim isomerase untuk mengubah sukrosa menjadi glukosa yang nantinya akan saling berikatan membentuk ikatan $\beta$ 1,4 glikosida. Proses polimerisasi pada tahap terakhir, Acetobacter xylinum mengeluarkan enzim polimerase untuk membentuk selulosa bakteri (Muhsinin et al., 2017). Sedangkan menurut Krasteva et al. (2017) pembentukan selulosa bakteri terjadi melalui penyerapan glukosa di sekitar sel bakteri secara pasif. Kemudian terjadi proses isomerisasi pengubahan glukosa-6-fosfat menjadi glukosa-1-fosfat. Pada tahap ini isomer akan bereaksi dengan uridin-5-trifosfat (UTP) membentuk glukosa uridin difosfat (UDP). Selanjutnya terjadi pengubahan menjadi rantai 1,4 glucan linier oleh selulosa sintase. Kemudian siklik di-GMP akan mengaktifkan rantai 1,4 glukan linier sehingga rantai selulosa ini dapat dikeluarkan dari sel bakteri melalui pori-pori pada dinding sel. Apabila sumber glukosa tidak mencukupi maka bakteri akan mempergunakan jalur fruktosa melalui proses enzimatik. 
JOPS (Journal Of Pharmacy and Science)

Vol.4, No.2, Bulan Juni 2021, Hal. 12-28

p-ISSN: 2622-9919; e-ISSN: 2615-1006

Table I. Hasil kajian literature review

\begin{tabular}{|c|c|c|c|c|c|}
\hline Substrat & $\begin{array}{l}\text { Suhu dan } \\
\text { Waktu } \\
\text { Fermentasi }\end{array}$ & $\begin{array}{l}\text { Jumlah Starter } \\
\text { yang digunakan }\end{array}$ & $\begin{array}{l}\text { Penambah } \\
\text { an selain } \\
\text { substrat }\end{array}$ & Karakterisasi & Pustaka \\
\hline $\begin{array}{l}\text { Ekstrak kulit } \\
\text { nanas, gula pasir } \\
10 \%(\mathrm{~b} / \mathrm{v}) \\
\text { ammonium } \\
\text { sulfat } 0,5 \% \\
(\mathrm{v} / \mathrm{v})\end{array}$ & $\begin{array}{l}30^{\circ} \mathrm{C} \text { selama } \\
14 \text { hari } \mathrm{pH} 4.5\end{array}$ & $10 \%(\mathrm{v} / \mathrm{v})$ & & $\begin{array}{l}\text { SEM: } \\
\text { Adanya perlakuan HSB (high } \\
\text { speed mekanik) mengakibatkan } \\
\text { struktur membran menjadi lebih } \\
\text { berpori } \\
\text { Mechanical properties: } \\
\text { Membran mengalami penurunan } \\
\text { kekuatan tarik sebesar } 94 \% \text { dari } \\
\text { semula sebelum perlakuan HSB } \\
\text { 308,17 Mpa menjadi } 159,16 \\
\text { Mpa }\end{array}$ & $\begin{array}{l}\text { (Muhajir et al., } \\
\text { 2018) }\end{array}$ \\
\hline $\begin{array}{l}\text { Ekstrak jeruk } \\
\text { afkir, sukrosa } \\
\text { dengan } 4 \\
\text { perlakuan yakni: } \\
0 \%, 2,5 \%, 5 \% \text {, } \\
7,5 \% \text { serta } \\
\text { ammonium } \\
\text { sulfat dengan } 3 \\
\text { perlakuan yakni: } \\
0,5 \%, 0,6 \%, \\
0,7 \%\end{array}$ & $\begin{array}{l}28-30^{\circ} \mathrm{C} \\
\text { selama } 10 \text { hari } \\
\text { pH } 4\end{array}$ & $10 \%(\mathrm{v} / \mathrm{v})$ & & $\begin{array}{l}\text { Kadar air: } \\
\text { Semakin meningkatnya } \\
\text { konsentrasi sukrosa dan } \\
\text { ammonium sulfat maka kadar } \\
\text { air yang dihasilkan semakin } \\
\text { rendah yakni } 88,49 \%\end{array}$ & $\begin{array}{l}\text { (Novita et al., } \\
\text { 2016) }\end{array}$ \\
\hline $\begin{array}{l}\text { Ekstrak jerami } \\
\text { nangka, sukrosa } \\
250 \mathrm{~g} \text {, asam } \\
\text { asetat } 5 \% \\
\text { ammonium } \\
\text { sulfat } 25 \mathrm{~g} \text {. }\end{array}$ & $\begin{array}{l}20-25^{\circ} \mathrm{C} \\
\text { selama } 10 \text { hari } \\
\text { pH } 4\end{array}$ & $4,6,8,10(\mathrm{v} / \mathrm{v})$ & $\begin{array}{l}\text { Asam } \\
\text { asetat } 5 \% \\
\text { atau } \\
\text { sampai } \mathrm{pH} \\
4\end{array}$ & $\begin{array}{l}\text { Kadar air: } \\
\text { Kadar air tertinggi terdapat pada } \\
\text { starter } 8 \% \text { dengan konsentrasi } \\
\text { air } 99 \% \text { namun menurun seiring } \\
\text { penambahan starter yang lebih } \\
\text { tinggi }\end{array}$ & $\begin{array}{l}\text { (Rose } \text { et al., } \\
\text { 2018) }\end{array}$ \\
\hline $\begin{array}{l}\text { limbah kulit } \\
\text { durian }\end{array}$ & $\begin{array}{l}28^{\circ} \mathrm{C} \text { selama } \\
10 \text { hari pH } 6\end{array}$ & $8 \%(\mathrm{v} / \mathrm{v})$ & & $\begin{array}{l}\text { SEM: } \\
\text { Medium limbah kulit durian } \\
\text { struktur lebih kompak dengan } \\
\text { pori-pori lebih tidak terlihat } \\
\text { sementara pada medium HS } \\
\text { struktur lebih berpori }\end{array}$ & $\begin{array}{l}\text { (Luo et al., } \\
\text { 2017) }\end{array}$ \\
\hline $\begin{array}{l}\text { Ekstrak limbah } \\
\text { tembakau 1L, } \\
\text { fruktosa, } \\
\text { glukosa, } \\
\text { manosa/sukrosa } \\
\text { masing" } 5 \mathrm{~g} / \mathrm{L}\end{array}$ & $\begin{array}{l}16 \text { hari suhu } \\
30^{\circ} \mathrm{C} \text { dengan } \\
\text { dua tahap } \\
\text { yakni: } \\
\text { Tahap 1: } \\
\text { selama } 7 \text { hari } \\
\text { dipanen } \\
\text { Tahap II: } \\
\text { dilanjutkan } \\
\text { sampai } 16 \text { hari } \\
\text { pH 6,5 }\end{array}$ & $10 \%(\mathrm{v} / \mathrm{v})$ & $\begin{array}{l}0,2 \mathrm{M} \\
\mathrm{NaOH}\end{array}$ & $\begin{array}{l}\text { SEM: } \\
\text { Selulosa bakteri yang diperoleh } \\
\text { pada medium limbah tembakau } \\
\text { secara keseluruhan permukaan } \\
\text { fiber lebih halus dengan struktur } \\
\text { jaringan sangat padat/rapat } \\
\text { dibandingkan medium HS } \\
\text { TGA: } \\
\text { Selulosa bakteri yang diperoleh } \\
\text { dari medium limbah tembakau } \\
\text { maupun HS stabil pada } \\
\text { suhu }<250^{\circ} \mathrm{C} \text {. pada suhu } 250 \text { - } \\
340^{\circ} \mathrm{C} \text { sebanyak } 60 \% \text { BC } \\
\text { terdegradasi/terurai sementara } \\
\text { pada suhu } 500{ }^{\circ} \mathrm{C} \text { sebanyak } 10 \text { - } \\
20 \% \text { tidak terurai }\end{array}$ & (Ye et al., 2019) \\
\hline
\end{tabular}


JOPS (Journal Of Pharmacy and Science)

Vol.4, No.2, Bulan Juni 2021, Hal. 12-28

p-ISSN: 2622-9919; e-ISSN: 2615-1006

$\begin{array}{lll}\text { limbah kulit } & 4 \text { hari suhu } & 4 \%(\mathrm{v} / \mathrm{v}) \\ \text { kentang } & 30^{\circ} \mathrm{C} \mathrm{pH} 6 & \end{array}$

$\begin{array}{ll}\text { Media Hs } & 28^{\circ} \mathrm{C} \text { selama } \quad 5 \%(v / v) \\ & 3-10 \text { hari }\end{array}$

Limbah cair sagu, gula konsentrasi $0 \%$ (bebas gula), $5 \%, 10 \%$ dan $15 \%(\mathrm{~b} / \mathrm{v})$

\author{
14 hari suhu $\quad 10 \%(\mathrm{v} / \mathrm{v})$ \\ $28-30^{\circ} \mathrm{C}$ pH 5
}

$20-25^{\circ} \mathrm{C}$

selama 14 hari

$\mathrm{pH} 4$

$10,20,30,40 \%(\mathrm{v} / \mathrm{v}$

)

pasir 30ml dari

$400 \mathrm{ml}$ volume

filtrate

ditambahkan

ammonium

sulfat $1 \mathrm{ml}$

limbah cair

tahu: air kelapa

(1:1) dan (1:3) $20-25^{\circ} \mathrm{C}$
selama 14 hari
pH 4-5
$1 \mathrm{M} \mathrm{NaOH}$ SEM:

Selulosa bakteri yang dihasilkan pada medium limbah kulit

kentang memperlihatkan struktur jaringan fiber yang homogen dan lebih lebar dengan luas permukaan yang tinggi

\section{SEM:}

Penggunaan metode keringbeku pada membran mengakibatkan struktur permukaan serat pori-porinya menjadi lebih terlihat sementara pada membran yang dikeringkan dengan oven struktur pori-pori serat lebih rapat dan tidak terlihat

Asam
asetat
glasial
sampai pH
5

SEM:

Pada konsentrasi penambahan gula $10 \%$ memperlihatkan jaringan lebih padat dan lebih halus jika dibandingkan konsentrasi lainnya. Struktur kurang rapat dan longgar pada Konsentrasi 5\%

Mechanical Properties:

Limbah cair sagu menghasilkan kekuatan tarik 44-87,3Mpa dengan hasil paling tinggi pada penambahan $10 \%(\mathrm{~b} / \mathrm{v})$ gula

\section{Kadar air:}

Pada konsentrasi inokulum A.xylinum $10 \%$ menghasilan kadar air tertinggi 87,6\% sementara pada inokulum $30 \%$ menghasilkan nilai terendah $85,8 \%$.

Asam
asetat pH
$4-5$

\section{Kadar air:}

Kadar air terbaik diperoleh dengan perbandingan 1:1 yakni
(Abdelraof $e t$ al., 2019)

(Ullah et al., 2017)

(Yanti et al., 2021)

(Marlinda \& Hartati, 2019) sebesar 86,75

\section{B. Substrat}

Medium Hestrin schramm (HS) merupakan media standart yang sering dipergunakan untuk memproduksi membran selulosa bakteri. Selulosa bakteri yang dihasilkan menghasilkan struktur dengan ukuran pori yang tersusun secara baik dengan porositas pori yang tinggi (Malmir et al., 2020). Struktur selulosa yang semakin rapat menghasilkan ukuran pori yang semakin kecil sehingga cairan akan sangat sulit untuk berdifusi (Aulia et al., 2020). Prositas sangat memiliki pengaruh terhadap kinerja membran yang dihasilkan dimana semakin tinggi porositas maka semakin tinggi membran tersebut menyerap air (Al-shamary \&Darwash, 2013).Perbandingan media dilakukan antara HS, Yamanaka (Y) dan Zhou (Z) dengan modifikasi sumber karbon yang berbeda disetiap medium. Modifikasi tersebut menggunakan sukrosa, sukrosa food grade, glukosa, mannitol, sirup kurma. Hasil produksi dengan medium mannitol menghasilkan kristalinitas tinggi, 
lebih stabil pada suhu dekomposisi yang lebih tinggi dan menghasilkan struktur jaringan serat lebih kompak. Mannitol dan sukrosa dapat meningkatkan produksi selulosa (Mohammadkazemi et al., 2015). Menurut Al-shamary \&Darwash (2013) penggunaan sukrosa sebagai sumber karbon mengakibatkan membran selulosa bakteri yang dihasilkan memiliki ketebalan paling rendah dengan porositas yang lebih tinggi, sementara pada medium glukosa menghasilkan membran dengan massa yang lebih tinggi dibanding fruktosa dan sukrosa. Penggunaan medium HS memiliki kelemahan yakni tingginya proses produksi. Hal ini dikarenakan medium tersebut memerlukan tambahan sumber nutrisi lain seperti ragi, pepton dan lainnya sehingga banyak penelitian mengeksplorasi sumber media lainnya dengan biaya yang lebih rendah, ekonomis dan efisien (Ye et al., 2019).

Medium limbah tembakau memiliki keunggulan yakni bahan baku sangat melimpah, biaya relatif rendah, dan tingginya kandungan sumber karbon seperti sukrosa, fruktosa, glukosa serta kandungan polisakarida lainnya. Substrat ini menghasilkan struktur yang mempunyai kemiripan dengan medium HS, mampu menghasilkan selulosa bakteri mencapai 5,2g/L. Hal ini mengalami peningkatan sebesar 1,6 kali dibanding medium HS melalui metode fermentasi 2 tahapan pemanenan selama 16 hari dengan dibuat perbandingan 1:10 rasio padat-cair. Pada medium ini selulosa yang dihasilkan membentuk permukaan lebih halus dan struktur jaringan yang rapat dibandingkan medium HS. Namun media ini memiliki kekurangan yakni tingginya kandungan nikotin. Kandungan nikotin yang tinggi dapat menghambat proses pembentukan selulosa sehingga memerlukan pengilangan kadar nikotin. (Ye et al., 2019).

Medium limbah kulit kentang memiliki keunggulan yakni bahan baku sangat melimpah, biaya relatif rendah, memiliki kandungan banyak pati serta polifenol, protein dan kandungan lemak yang sedikit sehingga cocok untuk dipergunakan sebagai media proses produksi. Selulosa bakteri yang dihasilkan pada medium limbah kulit kentang memperlihatkan struktur jaringan serat yang homogen dengan tingginya luas permukaan. Selain itu medium limbah kulit kentang yang dihidrolisis menggunakan asam nitrat encer dapat ditingkatkan produksi selulosa yang dihasilkan menjadi 2,2 kali lebih tinggi jika dibandingkan menggunakan medium HS. Hal ini dikarenakan metode tersebut mampu mencegah tingginya konsentrasi gula. Konsentrasi gula yang tinggi dapat mengakibatkan $\mathrm{pH}$ fermentasi menjadi turun dan menghambat suplai oksigen sehinga pembentukan selulosa dapat terhambat (Abdelraof et al.,2019).

Limbah cair sagu memiliki keunggulan, biaya relatif rendah, kaya akan kandungan nutrient meliputi protein, karbohidrat serta bahan lainnya. Menghasilkan kuat tarik $442 \times 10^{5}$ Newton dan Elongasi 4,8-5,8 \%. Pada konsentrasi penambahan gula $10 \%$ memperlihatkan jaringan lebih padat dan lebih halus (Yanti et al., 2021). Jika konsentrasi gula yang ditambahkan melebihi $10 \%$ maka akan menyebabkan terjadinya plasmolisis di dalam sel bakteri tersebut, sehingga terbentuknya membran sel selulosa akan berkurang dan menurunkan rendemen. Plasmolisis merupakan kondisi keluarnya cairan didalam sel mikroba akibat konsentrasi medium lebih tinggi sehingga mengakibatkan membran sel bakteri akan menyusut dan terpisah dari dinding sel. Apabila konsentrasi gula terlalu rendah mengakibatkan produksi selulosa bakteri akan menurun dikarenakan kekurangan substrat yang akan dikonversi menjadi membran selulosa (Iskandar et al., 2010).

Limbah kulit nanas memiliki keunggulan yakni memiliki biaya relatif rendah dengan kandungan kulit nanas 20,87\% serat kasar, 17,53\% karbohidrat, 4,41\% protein, 13,65\% gula reduksi dan $72 \%$ air. Hasil pemanfaatannya mampu menghasilkan berat kering selulosa bakteri sebanyak 3,3948gram dengan konsentrasi 80 \% (Junaidi \&Azlan, 2012). Struktur permukaan yang dihasilkan lebih longgar. Adanya perlakuan HSB (high speed blender) mengakibatkan struktur membran menjadi lebih berpori dengan ukuran yang lebih lebar. Dengan adanya perlakuan mekanik dapat menurunkan kristalinitas serta kuat tarik dari selulosa bakteri yang dihasilkan (Muhajir et al., 2018).Sedangkan media lainnya dapat digunakan selain berbiaya relatif murah, mengandung karbohidrat sebagai sumber karbon, sumber nitrogen dan nutrisi lain yang dibutuhkan untuk pertumbuhan selulosa bakteri. Tingginya kadar nitrogen mampu meningkatkan pembentukan 
kadar serat didalam selulosa bakteri yang dihasilkan (Yanti et al., 2020). Namun apabila dalam medium kandungan nitrogen melebihi batas maksimum maka produksi selulosa bakteri akan menurun (Izzati et al., 2019).

Penambahan asam asetat glasial sampai mencapai $\mathrm{pH}$ 4-5 saat proses fermentasi bertujuan untuk mengatur tingkat keasaman media fermentasi selulosa bakteri (Yanti et al., 2020). Bakteri Acetobacter xylinum mampu tumbuh pada pH 3-4 (Aulia et al., 2020). Penambahan senyawa asam organik seperti asam asetat, asam sitrat, dan senyawa asam organik lainnya mampu meningkatkan metabolisme bakteri dalam memproduksi membran selulosa serta mengurangi terjadinya pembentukan produk senyawa samping (Sharma \& Bhardwaj, 2019). Penambahan $\mathrm{NaOH}$, berfungsi mengatur kondisi tingkat keasaman $\mathrm{pH}$ medium yang akan dipergunakan pada proses fermentasi (Ye et al., 2019).

\section{Persentase bakteri yang digunakan}

Konsentrasi inokulum 10-20\% merupakan konsentrasi bakteri yang optimal untuk menghasilkan membran selulosa (Izzati et al., 2019). Apabila konsentrasi bakteri terlalu rendah maka kadar air yang dihasilkan semakin tinggi sehingga mengakibatkan kuat tarik membran menjadi lemah (Shobib et al., 2019). Sementara jika konsentrasi bakteri terlalu tinggi serat yang terbentuk makin banyak dan ikatan hidrogen yang terbentuk antar serat semakin kuat (Khusna et $a l ., 2020)$. Ikatan hidrogen yang kuat akan meningkatkan kuat tarik membran (Mondal, 2015).

\section{Kondisi fermentasi}

Menurut Nining (2019) pH 4 merupakan kondisi yang optimal bakteri Acetobacter xylinum untuk menghasilkan membran selulosa. Kondisi tersebut mengalami penurunan $\mathrm{pH}$ selama berlangsungnya proses fermentasi menjadi 3,37-3,42. Hal ini dikarenakan terjadi proses perombakan gula menjadi asam asetat dan asam glukonat (Wardhana et al.,2016). Bakteri Acetobacter xylinum mampu bertahan pada kondisi $\mathrm{pH}$ asam yang ekstrim yakni 3-4, tetapi proses produksi selulosa terganggu dan proses pembentukkannya kurang optimal sehingga menghasilkan sedikit selulosa (Zahan et al., 2015b). Ketika proses pembentukan selulosa kurang optimal mengakibatkan pembentukan struktur ikatan hidrogen antar serat kurang maksimal sehingga kemungkinan besar sangat berpengaruh terhadap hasil pengujian karakterisasi. Sedangkan menurut Iskandar et al. (2010) pertumbuhan bakteri yang optimum terjadi pada $\mathrm{pH}$ 5,4-6,3. Sementara pada penelitian Ye et al. (2019) proses fermentasi pembentukan selulosa bakteri dilakukan pada $\mathrm{pH}$ 6,5. Pengkondisian $\mathrm{pH}$ tersebut kemungkinan bertujuan untuk meminimalkan penurunan $\mathrm{pH}$ menjadi sangat asam selama berlangsungnya proses fermentasi serta memaksimalkan proses produksi selulosa. Menurut Abdelraof et al. (2019) dengan kondisi pH 6 mampu setidaknya menghasilkan $80 \%$ membran selulosa bakteri. Produktivitas selulosa bakteri berbanding lurus dengan penurunan $\mathrm{pH}$ dan konsumsi gula. Penurunan $\mathrm{pH}$ di dalam medium terjadinya karena adanya proses reaksi konversi enzimatik molekul glukosa secara cepat oleh glukosa dehydrogenase (GDH) kedalam bentuk asam glukonat dari bakteri Acetobacter xylinum. Pembentukkan asam 5-keto-glukonat dan asam glukonat sangat berperan penting didalam penyebab penurunan $\mathrm{pH}$ medium fermentasi (Junaidi \&Azlan, 2012). Sementara menurut Zahan et al. (2015b) faktor penyebab utama penurunan produksi selulosa selama proses fermentasi bukan dikarenakan asam glukonat melainkan dikarenakan adanya peningkatan pembentukan produk samping asam asetat sementara pembentukan asam glukonat terjadi secara konstan.

Selulosa bakteri dapat tumbuh dengan optimal pada suhu $28-31{ }^{\circ} \mathrm{C}$, sementara jika suhu terlalu tinggi maupun rendah maka membran selulosa yang dihasilkan kualitasnya akan menurun (Latumahina et al., 2017). Penelitian Junaidi \&Azlan. (2012) menyebutkan pada suhu $29-30,51^{\circ} \mathrm{C}$ selulosa bakteri yang diproduksi meningkat. Namun kondisi optimum terjadi pada suhu $30,51^{\circ} \mathrm{C}$ dengan mampu menghasilkan berat kering selulosa 3,3948 g. Sementara menurut Zahanet al.(2015a)pada suhu tersebut produksi selulosa bakteri mengalami penurunan. Sedangkan pada suhu $28^{\circ} \mathrm{C}$ merupakan kondisi optimum sehingga dapat menghasilkan $0,3722 \mathrm{~g} / 1$ selulosa bakteri 
dalam berat kering. Suhu fermentasi mempunyai peranan begitu penting dalam pertumbuhan bakteri Acetobacter xylinum. Suhu yang sangat tinggi lebih dari $35^{\circ} \mathrm{C}$ maka bakteri tersebut tidak bisa berkembangbiak. Hal ini dikarenakan komponen seluler pada bakteri mengalami kerusakan sehingga terjadi pembentukan sel mutan. Selain itu proses fermentasi yang tidak dilakukan pada suhu optimum dapat mengakibatkan terganggunya stabilitas kimia dan mekanik membran selulosa yang dihasilkan yang disebabkan oleh rendahnya ikatan hidrogen dan ikatan glikosida yang terbentuk (Sutrisno et al., 2019).

Selulosa bakteri semakin banyak dihasilkan ketika waktu fermentasi yang diperlukan semakin lama (Aulia et al., 2020). Dengan semakin banyaknya selulosa yang terbentuk maka ikatan hidrogen antar serat semakin kuat (Khusna et al., 2020). Namun pada penelitian Abdelraof et al. (2019) proses fermentasi yang dilakukan selama 4 hari dapat menghasilkan selulosa bakteri 2,61g/l. Hal tersebut dikarenakan adanya perlakuan hidrolisis asam nitrat encer dapat mencegah tingginya konsentrasi gula, yang nantinya dapat menurunkan $\mathrm{pH}$ sehingga dapat menghambat proses fermentasi. Pada rentang 5 hari tersebut akan banyak proses pengeluaran enzim ekstraseuler polimerase oleh bakteri Acetobacter xylinum untuk membentuk selulosa. Proses penyusunan polimer glukosa pada fase ini sangatlah penting dalam penentuan tingkat cepat lambatnya pembentukan selulosa bakteri oleh strain Acetobacter.xylinum (Wibowo \&Isroi, 2015). Penelitian Hamad et al.(2014) menyebutkan proses pembentukan selulosa bakteri yang optimal setelah ditambahkannya starter bakteri Acetobacter xylinum terjadi selama 7-13 hari dikarenakan pada masa tersebut bakteri masih berada pada fase eksponensial. Sedangkan setelah 13 hari proses fermentasi membran selulosa bakteri tidak akan terbentuk dikarenakan berkurangnya nutrient yang terdapat pada medium dan terdapat pertumbuhan metabolit sekunder berupa asam asetat yang tinggi sehingga pertumbuhan bakteri Acetobacter xylinum terhambat (Aulia et al., 2020).

Pemurnian pada membran juga memiliki pengaruh terhadap karakteristik selulosa yang dihasilkan, mayoritas jurnal kajian yang diperoleh melakukan pemurnian dengan metode hidrolsisis alkali. Pemurnian membran selulosa bakteri dengan $\mathrm{NaOH} 0,1 \%$ pada suhu $100^{\circ} \mathrm{C}$ selama 30 menit menghasilkan sifat fisik dan mekanis lebih baik daripada suhu $30{ }^{\circ} \mathrm{C}$ selama 24 jam (Yasa et al., 2020). Penggunaan $\mathrm{NaOH}$ untuk memurnikan membran selulosa bakteri yang dihasilkan dapat menurunkan porositas membran. Penurunan terjadi dikarenakan diameter fibril yang meningkat (Al-shamary \&Darwash, 2013). Konsentrasi $\mathrm{NaOH}$ yang digunakan melebihi 5\% maka mengakibatkan permukaan membran selulosa bakteri menjadi kasar dan kuat tarik menurun. Penurunan terjadi karena konsentrasi $\mathrm{NaOH}$ yang tinggi dapat mengikis atau melarutkan serat selulosa sehingga ikatan hidrogen yang terdapat pada struktur jaringan serat menjadi lemah (Sutrisno et al., 2019). Selain penggunaan pelarut alkali $\mathrm{NaOH}$, metode pengeringan juga sangat berpengaruh terhadap karakteristik selulosa yang dihasilkan. Metode kering beku dapat menjaga porositas membran dengan sangat baik dibanding dengan pemanasan pada suhu tinggi (Al-shamary \&Darwash, 2013)

\section{E. Karakterisasi}

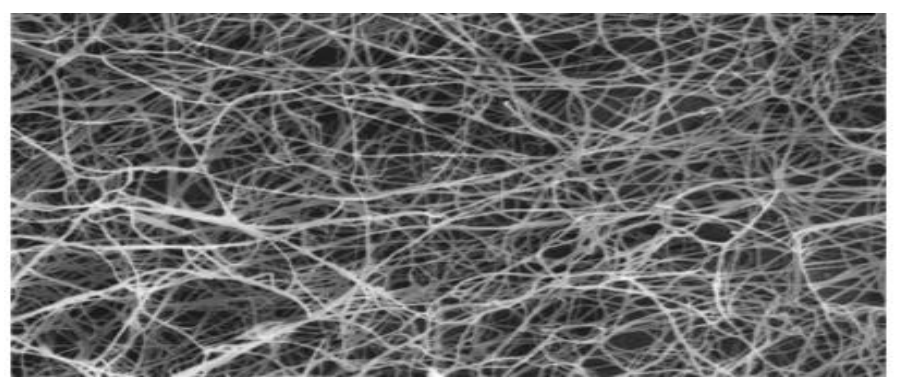

Gambar 2. Pengamatan struktur membran selulosa bakteri dengan pemeriksaan SEM (Shao et al., 2016) 
Pemeriksaan SEM dilakukan dengan melapisi sampel selulosa bakteri menggunakan emas kemudian diberi tegangan $25 \mathrm{kV}$, selanjutnya diamati dibawah mikroskop dengan perbesaran yang sesuai. Tujuan dilakukan pemeriksaan ini adalah untuk mengetahui porositas membran selulosa bakteri yang dihasilkan, semakin tinggi porositas membran maka kuat tarik menurun (Mondal, 2015). Penelitian Jia et al.(2017) menghasilkan serat selulosa bakteri berbentuk pita dengan diameter 50nm. Hasil yang sama terdapat pada penelitian Yan et al. (2017) serat selulosa bakteri yang dihasilkan berdiameter 8-40nm. Ukuran serat selulosa yang kecil memungkinkan saling membentuk ikatan hidrogen yang kuat sehingga terbentuk rongga pada membrane selulosa. Adanya ikatan hidrogen membuat membran tersebut bermuatan ionik sehingga dapat memuat berbagai bahan yang di tambahkan dengan sangat baik (Volova et al., 2018).

Kadar air selulosa bakteri dapat diketahui dengan mengukur berat kering dan berat basah. Adapun tujuan pengukuran kadar air ialah untuk mengetahui kualitas selulosa bakteri yang dihasilkan (Yanti et al.,2020). Kadar air pada membran sangat menentukan kekenyalan, tekstur maupun struktur permukaan (Rose et al.,2018). Menurut Suripto et al.(2018) selulosa bakteri yang baik mengandung kadar air lebih dari $85 \%$. Kadar air yang tinggi mengakibatkan selulosa bakteri mempunyai tekstur yang kenyal. Tingginya kadar air selulosa bakteri disebabkan oleh adanya gugus hidroksil, sehingga dapat mengikat gugus hidrogen pada air (Rose et al.,2018). Membran yang mengandung kadar air tinggi sangat cocok diaplikasikan untuk balutan luka karena membran tersebut dapat mengatur kelembapan area luka. Area luka yang lembab dapat mempercepat proses penyembuhan dibandingkan dalam kondisi kering disamping itu dapat mempermudah proses mengganti balutan tanpa menimbulkan rasa sakit pada kulit (Gupta et al., 2019).

Pemeriksaan stabilitas termal selulosa bakteri dapat diketahui dengan menempatkan sebanyak $10 \mathrm{mg}$ sampel dalam instrument, kemudian setiap 1 menit suhu dinaikan $20^{\circ} \mathrm{C}$ sampai mencapai suhu $600^{\circ} \mathrm{C}$ dengan instrument perkin elmer ; Shelton, USA(Mondal, 2015). Pengukuran TGA bertujuan untuk mengevaluasi stabilitas termal dan kristalinitas serat selulosa bakteri yang dihasilkan (Mondal, 2015). Pada penelitian Ye et al. (2019) selulosa bakteri yang diperoleh dari medium limbah tembakaumaupun HS memilki kesamaan yakni pada kisaran suhu $250-340^{\circ} \mathrm{C}$ terjadi pengurangan berat membran sebanyak 60\%. Menurut Vasconcelos et al. (2017) degradasi termal pada selulosa terjadi melalui 3 tahapan yakni pertama suhu berkisar $50-150^{\circ} \mathrm{C}$ diakibatkan oleh penguraian air yang terkandung dalam membran, kedua suhu berkisar $250-400^{\circ} \mathrm{C}$ diakibatkan oleh hilangnya massa selulosa yang tinggi berkaitan dengan adanya dekomposisi, dehidrasi serta depolimerisasi unit glikosida. ketiga suhu berkisar $400-600^{\circ} \mathrm{C}$ berkaitan dengan proses dekomposisi residu karbon serta proses oksidasi sehingga menghasilkan produk gas yang memiliki berat molekul yang rendah. Hasil penelitian Yan et al. (2017) selulosa bakteri yang dilakukan proses hidrolisis asam menggunakan asam sulfat dapat menghasilkan suhu dekomposisi lebih tinggi $350{ }^{\circ} \mathrm{C}$ dibandingkan seluosa bakteri tanpa perlakuan $305{ }^{\circ} \mathrm{C}$. Meningkatnya suhu dekomposisi dikarenakan asam sulfat mampu menghilangkan komponen amorf yang terdapat pada selulosa bakteri dan kristalinitas membran meningkat (Yan et al., 2017).

Kuat tarik membran selulosa bakteri dapat ditentukan menggunakan suatu instrumen. Pengujian dilakukan menggunakan 25 sampel, setiap sampel diberi tegangan 5 Newton/menit sampai membran putus kemudian dihitung menggunakan rumus dan nilai yang diperoleh diambil rata-rata (Mondal, 2015). Pengukuran kuat tarik bertujuan untuk mengukur kuat membran dan sifat mekanisnya (Yasa et al., 2020). Semakin tinggi kuat tarik maka semakin bagus kualitas membran yang dihasilkan (Iskandar et al., 2010). Hasil kuat tarik selulosa bakteri dipengaruhi dengan banyaknya gula yang ditambahkan pada proses fermentasi, dengan meningkatnya jumlah gula yang ditambahkan maka kuat tarik akan meningkat. Namun kuat tarik akan menurun apabila gula yang ditambahkan terlalu berlebihan (Yanti et al., 2021). Selulosa bakteri memiliki struktur nanokristalin dan mikrofibril sehingga menunjukkan kemampuan kuat mekanik yang sangat baik. Selulosa bakteri memiliki kuat tarik 200-300Mpa(Mondal, 2015). Besarnya nilai kuat tarik membran selulosa yang dihasilkan untuk penggunaan bioplastik menurut standar yakni $10-100 \mathrm{Mpa}$ (Yasa et al., 2020). Sedangkan untuk bahan polipropilen (PP) 24-302 Mpa, sementara untuk bahan 
polietilen dengan densitas rendah 16-18 Mpa (Yanti et al., 2021). Apabila lapisan pori pada permukaan selulosa bakteri sedikit tertutupi maka luas permukaan akan semakin besar, sehingga menghasilkan kuat putus yang kecil ( $\mathrm{P}=\mathrm{F} / \mathrm{A})$ dengan $\mathrm{F}$ ialah gaya sedangkan $\mathrm{A}$ ialah luas penampang. Sedangkan nilai elongasi berbanding terbalik dengan nilai kuat tarik. Semakin besar nilai kuat tarik maka nilai elongasi akan menurun (Yasa et al., 2020).

\section{F. Manfaat selulosa bakteri dibidang farmasi \\ Pembalut luka}

Selulosa bakteri memiliki daya serap yang tinggi karena adanya struktur jaringan fibrous berporositas tinggi dengan sifat yang sangat hidrofilik (Qiu et al., 2016). Keunikan tersebut membuat membran mempunyai kemampuan menyerap eksudat luka dan mengkondisikan kelembapan area luka, sehingga luka menjadi lebih cepat sembuh. Kelembapan sangat penting dalam proses pengantian balutan tanpa menimbulkan rasa sakit dan trauma pada kulit (Gupta et al., 2019). Namun selulosa bakteri memiliki kelemahan tidak dapat mencegah terjadinya infeksi sehingga perlu penambahan suatu bahan aktif pada membran selulosa bakteri yang berfungsi untuk mencegah terjadinya infeksi sehingga mempercepat proses penyembuhan luka (Wahid, et al., 2019). Pada penelitian Shao et al.(2016) menambahkan senyawa tetrasiklin pada membran selulosa bakteri sehingga dapat menghambat bakteri gram positif dan negatif. Namun penggunaan antibiotik dikhawatirkan akan menimbulkan bakteri pathogen yang kebal terhadap pengobatan. Beberapa penelitian mencari alternatif pengganti antibiotik diantaranya dengan menambahkan seng oksida, perak dan kitosan (Wahid, et al., 2019). Sedangkan penelitian lain menambahkan sericin sutra (SS) dan pemberian antiseptik polyhexamethylene biguanide (PHMB) pada membran selulosa, selain dapat menghambat bakteri gram positif dan negatif. Penambahan senyawa tersebut dapat meningkatkan pembentukan kolagen dan fibroblast tipe 1 yang stabil (Boni et al., 2020).

\section{Rekayasa jaringan}

Selulosa bakteri mempunyai elestisitas, kuat tarik tinggi dan tidak menimbulkan respon inflamasi sehingga dapat digunakan untuk aplikasi rekayasa jaringan. Membran selulosa bakteri digunakan untuk mengganti pembuluh darah arteri kecil dengan ukuran kurang dari $5 \mathrm{~mm}$. Selulosa bakteri ini lebih stabil dan jarang menimbulkan efek samping seperti dapat meminimalisir terjadinya resiko pembekuan darah pada penggunaan jangka panjang (Zhang et al., 2021). Hasil penelitian Bao et al. (2021). Selulosa bakteri digunakan untuk mengganti pembuluh darah kecil pada kelinci putih Selandia Baru dengan pengujian secara in vivo selama 46 hari, menunjukkan tidak terjadi efek toksisitas, reaksi inflamasi dan tidak terdapat tanda kebocoran ataupun kejadian pendarahan selama pengujian berlangsung.

\section{Pembawa obat}

Selulosa bakteri ditambahkan senyawa obat Famotidine \& Tizanidine, kemudian dievaluasi profil pelepasan obat secara in vitro pada metode kering beku dan metode oven dapat melepaskan molekul obat $80 \%$ selama 15 menit secara langsung (Badshah et al., 2017). Hasil berbeda terdapat pada penelitian Badshah et al. (2018) yang melakukan modifikasi membran selulosa dengan asetilasi. Pada metode kering beku dapat mengakibatkan pelepasan obat $80 \%$ secara lambat selama 1-3 jam dibandingkan metode kering panas.

\section{Penstabil emulsi}

Penggunaan surfaktan sebagai penstabil emulsi dapat menimbulkan berbagai masalah seperti: menyebabkan reaksi iritan pada kulit, menimbulkan dampak buruk untuk lingkungan karena sangat sulit terurai secara alami dan kurang efektif dalam menstabilkan minyak dalam air dengan ukuran yang sangat kecil (Jia et al., 2016). Oleh karena itu selulosa bakteri digunakan karena memiliki keunggulan seperti struktur yang lebih berpori dan kapasitas menyerap air yang tinggi sekitar $90 \%$, sehingga dapat digunakan sebagai penstabil emulsi (Novikov et al., 2021). Selulosa bakteri yang dihidrolisis menggunakan asam sulfat dapat menstabilkan emulsi dan 
menghasilkan zeta potensial yang tinggi 34,8mv. Tingginya zeta potensial disebabkan oleh adanya gugus karboksil yang diperoleh dari proses oksidasi cincin piranosa (Yan et al., 2017). Zeta potensial merupakan suatu parameter yang menunjukkan adanya gaya tolak antar partikel, umumnya digunakan untuk mengetahui sifat muatan permukaan pertikel (Pertiwi et al., 2018).Semakin tinggi zeta potensial, maka emulsi semakin stabil karena dapat mencegah terjadinya flokulasi. Semakin tinggi konsentrasi selulosa bakteri yang ditambahkan, maka emulsi yang distabilkan dengan ukuran kecil semakin homogen. Namun kestabilan akan menurun seiring dengan meningkatnya $\mathrm{pH}$ (Yan et al., 2017).

\section{Masker wajah}

Selulosa bakteri dapat digunakan untuk merawat kulit kering karena mempunyai keunggulan yakni: kadar air yang tinggi, permeabilitas membran yang sangat baik dan dapat melembabkan kulit. Keunggulan tersebut memudahkan terdistribusinya bahan aktif yang ditambahkan pada membran untuk menembus kedalam kulit (Perugini et al., 2018). Hasil penelitian Pacheco et al. (2017) selulosa bakteri yang digunakan sebagai masker pada 69 relawan, dengan intensitas pemakaian seminggu 3 kali dalam kurun waktu dua bulan. Selama penggunaan masker dapat merekat dengan baik pada kulit, kelembapan meningkat dan dapat meningkatnya hidrasi kulit mencapai $76 \%$, sehingga membran selulosa sangat potensial digunakan untuk merawat kulit (Pacheco et al., 2017). Sedangkan penelitian Perugini et al. (2018) melakukan pendekatan dengan metode yang berbeda yakni teknik non destruktif MLS, NIR dan pengujian secara in vivo. Eveluasi bertujuan untuk memastikan keamanan dan stabilitas dalam penggunaan membran selulosa bakteri sebagai masker. Pengujian dilakukan menggunakan dua masker selulosa bakteri yang berasal dari produsen yang berlainan, dengan mengevaluasi parameter seperti: viskositas, sifat organoleptik dan $\mathrm{pH}$. Hasil menunjukkan masker selulosa bakteri dapat digunakan dan diproduksi secara aman dengan masa simpan selama 6 bulan (Perugini et al., 2018).

\section{KESIMPULAN}

Substrat limbah kulit kentang dengan proses hidrolisis asam nitrat encer dapat menghasilkan selulosa bakteri yang lebih baik dibandingkan media sintesis. Konsentrasibakteri optimum pada 10-20\% dan $\mathrm{pH}$ optimum pada5,3-6,3. Berdasarkan review artikel ini, terdapat permasalahan seperti masih banyak bahan limbah lain yang belum banyak di manfaatkan dan memerlukanmetode fermentasi optimum yang dapat meningkatkan hasil produksi selulosa bakteri selain metode statis seperti: agitatif dan penggunaan bioreactor.

\section{DAFTAR PUSTAKA}

Abdelraof, M., Hasanin, M.S., El-Saied, H., 2019. Ecofriendly green conversion of potato peel wastes to high productivity bacterial cellulose. Carbohydr. Polym. 211, 75-83. https://doi.org/10.1016/j.carbpol.2019.01.095

Al-shamary, E.E., Darwash, A.K.A.-, 2013. Influence of Fermentation Condition and Alkali Treatment on the Porosity and Thickness of Bacterial Cellulose Membranes. Tojsat 3, 194203.

Aulia, N., Nurwantoro, Susanti, S., Rizqiati, H., Abduh, S.B.M., 2020. Pengaruh Periode Fermentasi terhadap Karakteristik Fisik, Kimia dan Hedonik Nata Sari Jambu Biji Merah 4, 131-136.

Badshah, M., Ullah, H., Khan, A.R., Khan, S., Park, J.K., Khan, T., 2018. Surface modification and evaluation of bacterial cellulose for drug delivery. Int. J. Biol. Macromol. 113, 526-533. https://doi.org/10.1016/j.ijbiomac.2018.02.135 
Badshah, M., Ullah, H., Khan, S.A., Park, J.K., Khan, T., 2017. Preparation, characterization and in-vitro evaluation of bacterial cellulose matrices for oral drug delivery. Cellulose 24, 50415052. https://doi.org/10.1007/s10570-017-1474-8

Bao, L., Hong, F.F., Li, G., Hu, G., Chen, L., 2021. Implantation of air-dried bacterial nanocellulose conduits in a small-caliber vascular prosthesis rabbit model. Mater. Sci. Eng. C 122, 111922. https://doi.org/10.1016/j.msec.2021.111922

Boni, B.O.O., Lamboni, L., Bakadia, B.M., Hussein, S.A., Yang, G., 2020. Combining Silk Sericin and Surface Micropatterns in Bacterial Cellulose Dressings to Control Fibrosis and Enhance Wound Healing. Eng. Sci. 68-77. https://doi.org/10.30919/es8d906

Das, S. and Dash, H. R. (2020) Microbial and Natural Macromolecules: Synthesis and Applications - Google Buku, Elsevier. Available at: https://books.google.co.id/books?id=E9PVDwAAQBAJ\&pg=PA313\&lpg=PA313\&dq=prod uction+of+nanocellulose+bacteria+and+utilization+in+the+pharmaceutical +sector\&source $=b$ 1\&ots=I-GFY3vjxo\&sig=ACfU3U03E4--64ji00d-h6-

GbhTeyQVTaQ\&hl=id\&sa=X\&ved=2ahUKEwi77KHcxs7tAhU1H7 (Accessed: 18 January 2021).

Gupta, A., Keddie, D.J., Kannappan, V., Gibson, H., Khalil, I.R., Kowalczuk, M., Martin, C., Shuai, X., Radecka, I., 2019. Production and characterisation of bacterial cellulose hydrogels loaded with curcumin encapsulated in cyclodextrins as wound dressings. Eur. Polym. J. 118, 437-450. https://doi.org/10.1016/j.eurpolymj.2019.06.018

Hamad, A., Handayani, N.A., Puspawiningtyas, E., 2014. Pengaruh Umur Starter Acetobacter xylinum Terhadap Produksi Nata De Coco ( Effects of the Starter Age of Acetobacter xylinum on the Nata de coco production ). Techno 15, 37-49.

Iskandar, Zaki, M., Mulyati, S., Fathanah, U., Sari, I., Juchairawati, 2010. Pembuatan Film Selulosa dari Nata de Pina. J. Rekayasa Kim. Lingkung. 7, 105-111.

Izzati, N., Irfan, I., Rohaya, S., 2019. Variasi Penggunaan Jenis Bahan Baku (Air Cucian Beras dan Air Kelapa) dengan Penambahan Ekstrak Tauge Terhadap Rendemen dan Mutu Nata. J. Ilm. Mhs. Pertan. 4, 300-307. https://doi.org/10.17969/jimfp.v4i2.10923

Jia, Y., Wang, X., Huo, M., Zhai, X., Li, F., Zhong, C., 2017. Preparation and characterization of a novel bacterial cellulose/chitosan bio-hydrogel. Nanomater. Nanotechnol. 7, 1-8. https://doi.org/10.1177/1847980417707172

Jia, Y., Zhai, X., Fu, W., Liu, Y., Li, F., Zhong, C., 2016. Surfactant-free emulsions stabilized by tempo-oxidized bacterial cellulose. Carbohydr. Polym. 151, 907-915. https://doi.org/10.1016/j.carbpol.2016.05.099

Jozala, A.F., Pértile, R.A.N., dos Santos, C.A., de Carvalho Santos-Ebinuma, V., Seckler, M.M., Gama, F.M., Pessoa, A., 2015. Bacterial cellulose production by Gluconacetobacter xylinus by employing alternative culture media. Appl. Microbiol. Biotechnol. 99, 1181-1190. https://doi.org/10.1007/s00253-014-6232-3

Junaidi, Z., Azlan, N.M., 2012. Optimization of Bacterial Cellulose Production from Pineapple Waste: Effect of Temperature, pH and Concentration. 5th Eng. Conf. "Engineering Towar. Chang. - Empower. Green Solut. 1-7.

Khusna, A., Prastujati, A., Setiadevi, S., Hilmi, M., 2020. Effect of starter sources and old fermentation on making nata de whey towards chemical quality. E3S Web Conf. 142, 1-5. https://doi.org/10.1051/e3sconf/202014204001

Krasteva, P.V., Bernal-Bayard, J., Travier, L., Martin, F.A., Kaminski, P.A., Karimova, G., Fronzes, R., Ghigo, J.M., 2017. Insights into the structure and assembly of a bacterial cellulose secretion system. Nat. Commun. 8, 25-28. https://doi.org/10.1038/s41467-01701523-2

Latumahina, M., Awan, A., Rumahlatu, D., 2017. Pengaruh SuhudanLamaFermentasi Terhadap Uji Organoleptik Pada Pembuatan Nata Buah Enau (Areng pinnata Merr). Biopendix J. Biol. Pendidik. dan Terap. 4, 29-37. https://doi.org/10.30598/biopendixvol4issue1page29-37 
Luo, M.T., Zhao, C., Huang, C., Chen, X.F., Huang, Q.L., Qi, G.X., Tian, L.L., Xiong, L., Li, H.L., Chen, X. De, 2017. Efficient Using Durian Shell Hydrolysate as Low-Cost Substrate for Bacterial Cellulose Production by Gluconacetobacter xylinus. Indian J. Microbiol. 57, 393399. https://doi.org/10.1007/s12088-017-0681-1

Ma'ruf, M.T., 2018. Fiksasi Tulang Dengan Alat Berbahan Dasar Polimer (Uji Biokompatibilitas). Interdental J. Kedokt. Gigi 14, 27-31. https://doi.org/10.46862/interdental.v14i2.371

Malmir, S., Karbalaei, A., Pourmadadi, M., Hamedi, J., Yazdian, F., Navaee, M., 2020. Antibacterial properties of a bacterial cellulose CQD-TiO2 nanocomposite. Carbohydr. Polym. 234, 115835. https://doi.org/10.1016/j.carbpol.2020.115835

Mani, A. (2018) 'Food Preservation by Fermentation and Fermented Food Products', International Journal of Academic Research \& Development, (1), pp. 51-57.

Marlinda, Hartati, R., 2019. Optimalisasi Karakteristik Nata De Banana Skin Melalui Perubahan. J. Optim. 5, 52-59.

Mohammadkazemi, F., Azin, M., Ashori, A., 2015. Production of bacterial cellulose using different carbon sources and culture media. Carbohydr. Polym. 117, 518-523. https://doi.org/10.1016/j.carbpol.2014.10.008

Mondal, I.H., 2015. Cellulose and Cellulose Composites Modification, Characterization And Applications. Nova Science, New York.

Muhajir, M., Suryanto, H., Larasati, A., 2018. Struktur dan Sifat Mekanik Film Bacterial Cellulose dengan Disintegrasi Mekanis. JPSE (Journal Phys. Sci. Eng. 3, 55-62. https://doi.org/10.17977/um024v3i22018p055

Muhsinin, S., Putri, N.T., Ziska, R., Jafar, G., 2017. Bacterial cellulose from fermented banana peels (Musa paradisiaca) by Acetobacter xylinum as matrix of biocellulose mask. J. Pharm. Sci. Res. 9, 159-162.

Nining, S.A., 2019. Pengaruh Derajat Keasaman (pH) dan Konsentrasi BakteriAcetobacterxylinumterhadap kualitasNata De Pina.Naskah Publikasi Universitas Muhammadiyah Surakarta.

Novikov, I. V., Pigaleva, M.A., Naumkin, A. V., Badun, G.A., Levin, E.E., Kharitonova, E.P., Gromovykh, T.I., Gallyamov, M.O., 2021. Green approach for fabrication of bacterial cellulose-chitosan composites in the solutions of carbonic acid under high pressure $\mathrm{CO} 2$. Carbohydr. Polym. 258, 117614. https://doi.org/10.1016/j.carbpol.2021.117614

Novita, R., Hamzah, F., Restuhadi, F., 2016. Optimization of the Concentration of Sucrose and. Jom Faperta 3, 1-14.

Pacheco, G., de Mello, C.V., Chiari-Andréo, B.G., Isaac, V.L.B., Ribeiro, S.J.L., Pecoraro, É., Trovatti, E., 2017. Bacterial cellulose skin masks-Properties and sensory tests. J. Cosmet. Dermatol. 17, 840-847. https://doi.org/10.1111/jocd.12441

Pertiwi, R. D. et al. (2018) 'Pembuatan, Karakterisasi dan Uji In Vitro Nanopartikel Emas Berbasis Konjugat Gom Arab-Vinkristin', Jurnal Ilmu Kefarmasian Indonesia, 16(1), p. 6. doi: 10.35814/jifi.v16i1.486.

Perugini, P., Bleve, M., Cortinovis, F., Colpani, A., 2018. Biocellulose masks as delivery systems: A novel methodological approach to assure quality and safety. Cosmetics 5. https://doi.org/10.3390/cosmetics5040066

Potivara, K., Phisalaphong, M., 2019. Development and characterization of bacterial cellulose reinforced with natural rubber. Materials (Basel). 12. https://doi.org/10.3390/ma12142323

Qiu, Y., Qiu, L., Cui, J., Wei, Q., 2016. Bacterial cellulose and bacterial cellulose-vaccarin membranes for wound healing. Mater. Sci. Eng. C 59, 303-309. https://doi.org/10.1016/j.msec.2015.10.016

Rohaeti, E., Laksono FX, E.W., Rakhmawati, A., 2016. Kemudahan Biodegradasi Selulosa Bakteri dari Limbah Cucian Beras dengan Penambahan Gliserol, Kitosan, dan Nanopartikel Perak. J. Kim. Val. 2, 35-44. https://doi.org/10.15408/jkv.v2i1.3083

Rose, D., Ardiningsih, P., Idiawati, N., 2018. Karakteristik Nata de Jackfruit (Artocarpus 
heterophyllus) Dengan Variasi Konsentrasi StarterAcetobacter xylinum. J. Kim. Khatulistiwa $7,1-7$.

Shao, W., Liu, H., Wang, S., Wu, J., Huang, M., Min, H., Liu, X., 2016. Controlled release and antibacterial activity of tetracycline hydrochloride-loaded bacterial cellulose composite membranes. Carbohydr. Polym. 145, 114-120. https://doi.org/10.1016/j.carbpol.2016.02.065

Sharma, C., Bhardwaj, N.K., 2019. Biotransformation of fermented black tea into bacterial nanocellulose via symbiotic interplay of microorganisms. Int. J. Biol. Macromol. 132, 166177. https://doi.org/10.1016/j.ijbiomac.2019.03.202

Shimpi, N.G., 2018. Biodegradableing and Biocompatible Polymer Composites Process, Properties and Applications. WoodheadPublishing.

Shobib, A., Fatarina, E., Prasetiyo, J.A., 2019. Making Nata De Cassava From Rengginang Liquid Waste Using Acetobacter Xylium. Neo Tek. 5, 2-7. https://doi.org/10.37760/neoteknika.v5i2.1426

Suripto, P, U.S., Agustina, L., 2018. Identifikasi Mutu Pasca Panen Nata De Coco Berdasarkan Lama Perendaman Dan Perebusan. Inov. Agroindustri 1, 29-37.

Sutrisno, T.A., Suryanto, H., Wulandari, R., Muhajir, M., Zahari, S.M.S.N.S., 2019. The Effect of Chemical Pretreatment Process on Mechanical Properties and Porosity of Cellulose Bacterial Film. J. Mech. Eng. Sci. Technol. 3, 8-17. https://doi.org/10.17977/um016v3i12019p008

Ullah, H., Badshah, M., Mäkilä, E., Salonen, J., Shahbazi, M.A., Santos, H.A., Khan, T., 2017. Fabrication, characterization and evaluation of bacterial cellulose-based capsule shells for oral drug delivery. Cellulose 24, 1445-1454. https://doi.org/10.1007/s10570-017-1202-4

Vasconcelos, N.F., Feitosa, J.P.A., da Gama, F.M.P., Morais, J.P.S., Andrade, F.K., de Souza Filho, M. de S.M., Rosa, M. de F., 2017. Bacterial cellulose nanocrystals produced under different hydrolysis conditions: Properties and morphological features. Carbohydr. Polym. 155, 425-431. https://doi.org/10.1016/j.carbpol.2016.08.090

Volova, T.G., Prudnikova, S. V., Sukovatyi, A.G., Shishatskaya, E.I., 2018. Production and properties of bacterial cellulose by the strain Komagataeibacter xylinus B-12068. Appl. Microbiol. Biotechnol. 102, 7417-7428. https://doi.org/10.1007/s00253-018-9198-8

Wahid, F., Hu, X.H., Chu, L.Q., Jia, S.R., Xie, Y.Y., Zhong, C., 2019. Development of bacterial cellulose/chitosan based semi-interpenetrating hydrogels with improved mechanical and antibacterial properties. Int. J. Biol. Macromol. 122, 380-387. https://doi.org/10.1016/j.ijbiomac.2018.10.105

Wardhana, E., Rusmarilin, H., Yusraini, E., 2016. The Effect of Concentration of Sugar and pH on the Quality of Nata de Yammy from Yam Starch Waste Liquid. J. Rekayasa pangan dan Pert. 4, 323-331.

Wibowo, N.A., Isroi, 2015. Potensi In-Vivo SelulosaBakterial Sebagai Nano-Filler Karet Elastomer Thermoplastics( ETPS ).Perspektif 14, 103-112.

Yan, H., Chen, X., Song, H., Li, J., Feng, Y., Shi, Z., Wang, X., Lin, Q., 2017. Synthesis of bacterial cellulose and bacterial cellulose nanocrystals for their applications in the stabilization of olive oil pickering emulsion. Food Hydrocoll. 72, 127-135. https://doi.org/10.1016/j.foodhyd.2017.05.044

Yanti, N.A., Ahmad, S.W., Muhiddin, N.H., Ramadhan, L.O.A.N., Suriana, Walhidayah, T., 2021. Characterization of bacterial cellulose produced by acetobacter xylinum strain lkn6 using sago liquid waste as nutrient source. Pakistan J. Biol. Sci. 24, 335-344. https://doi.org/10.3923/pjbs.2021.335.344

Yanti, N.A., Isra, W.O., Parakkasi, V.N.R., 2020. Potensi Limbah Cair Tahu Sebagai Sumber Nitrogen Pada Produksi SelulosaBakteri 5, 9-17.

Yasa, I.W.S., Basuki, E., Saloko, S., Handito, D., 2020. Sifat Fisik Dan Mekanis Lembaran Kering Selulosa Bakteri Berbahan Dasar Limbah Hasil Pertanian. J. Ilm. Rekayasa Pertan. dan Biosist. 8, 89-99. https://doi.org/10.29303/jrpb.v8i1.170

Ye, J., Zheng, S., Zhang, Z., Yang, F., Ma, K., Feng, Y., Zheng, J., Mao, D., Yang, X., 2019. 
Bacterial cellulose production by Acetobacter xylinum ATCC 23767 using tobacco waste extract as culture medium. Bioresour. Technol. 274, 518-524. https://doi.org/10.1016/j.biortech.2018.12.028

Zahan, K. A. et al.2015a. 'Effect of Incubation Temperature on Growth of Acetobacter xylinum 0416 and Bacterial Cellulose Production', Applied Mechanics and Materials, 815, pp. 3-8. doi: 10.4028/www.scientific.net/amm.815.3.

Zahan, K. A., Pa'e, N. and Muhamad, I. I. 2015b. 'Monitoring the Effect of pH on Bacterial Cellulose Production and Acetobacter xylinum 0416 Growth in a Rotary Discs Reactor', Arabian Journal for Science and Engineering, 40(7), pp. 1881-1885. doi: 10.1007/s13369015-1712-z.

Zhang, Q., He, S., Zhu, X., Luo, H., Gama, M., Peng, M., Deng, X., Wan, Y., 2021. Heparinization and hybridization of electrospun tubular graft for improved endothelialization and anticoagulation. Mater. Sci. Eng. C 122, 111861. https://doi.org/10.1016/j.msec.2020.1118 